\title{
High Baseline C-Reactive Protein Level Can Predict the Occurrence of the Jarisch-Herxheimer Reaction in Patients with Active Syphilis
}

\author{
Yu-Ting Tseng, ${ }^{1,2}$ Pei-Yun Chou,' \\ Ming-Hong Tai, ${ }^{2,3}$ Chia-Yen Dai, ${ }^{4-6}$ \\ Susan Shin-Jung Lee, (1D ${ }^{1,7}$ Yao-Shen \\ Chen, $\mathbb{D}^{1,7}$ Hung-Chin Tsai, ${ }^{1,3,7,8 *}$ \\ Yen-Hsu Chen $\left(\mathbb{D}^{2,6,9-13 *}\right.$ \\ 'Division of Infectious Diseases, \\ Department of Medicine, Kaohsiung \\ Veterans General Hospital, Kaohsiung, \\ Taiwan; ${ }^{2}$ Graduate Institute of Medicine, \\ College of Medicine, Kaohsiung Medical \\ University, Kaohsiung, Taiwan; ${ }^{3}$ Institute of \\ Biomedical Sciences, National Sun Yat-sen \\ University, Kaohsiung, Taiwan; ${ }^{4}$ Hepatitis \\ Center and Hepatobiliary Division, \\ Department of Internal Medicine, Kaohsiung \\ Medical University Hospital, Kaohsiung, Taiwan; \\ ${ }^{5}$ Graduate Institute of Clinical Medicine, \\ College of Medicine, Kaohsiung Medical \\ University, Kaohsiung, Taiwan; ${ }^{6}$ School of \\ Medicine, College of Medicine, Kaohsiung \\ Medical University, Kaohsiung, Taiwan; ${ }^{7}$ Faculty \\ of Medicine, School of Medicine, National Yang- \\ Ming Chiao Tung University, Taipei, Taiwan; \\ ${ }^{8}$ Department of Parasitology, Kaohsiung \\ Medical University, Kaohsiung, Taiwan; \\ 'Division of Infectious Diseases, Department of \\ Internal Medicine, Kaohsiung Medical \\ University Hospital, Kaohsiung Medical \\ University, Kaohsiung, Taiwan; ${ }^{10}$ Sepsis \\ Research Center, Kaohsiung Medical \\ University, Kaohsiung, Taiwan; " Center of \\ Tropical Medicine and Infectious Diseases, \\ Kaohsiung Medical University, Kaohsiung, \\ Taiwan; ${ }^{12}$ Department of Biological Science \\ and Technology, College of Biological Science \\ and Technology, National Chiao Tung \\ University, HsinChu, Taiwan; ${ }^{13}$ Institute of \\ Medical Science and Technology, National Sun \\ Yat-sen University, Kaohsiung, Taiwan \\ *These authors contributed equally to this \\ work
}

Correspondence: Hung-Chin Tsai Division of Infectious Diseases, Department of Medicine, Kaohsiung Veterans General

Hospital, Kaohsiung, Taiwan

Email hctsail0II@yahoo.com.tw

Yen-Hsu Chen

Graduate Institute of Medicine, College of Medicine, Kaohsiung Medical University,

Kaohsiung, Taiwan

Email infchen@gmail.com
Background: The Jarisch-Herxheimer reaction (JHR) is an inflammatory reaction that can occur after treatment for syphilis. The mechanism of JHR is unknown. The level of C-reactive protein (CRP) increases during infection and inflammation. We hypothesized that CRP may be involved in the JHR in syphilitic patients at initial syphilis infection and also through interactions with benzathine penicillin-induced phagocytosis.

Methods: This prospective cohort study enrolled syphilitic adult patients with/without JHR between July 2018 and October 2020. Serum samples before and after the administration of the first dose of benzathine penicillin were obtained. The serum level of CRP was determined by ELISA. The Kruskal-Wallis test was used to compare the levels of CRP in different groups, and the Wilcoxon signed-rank test was used to compare changes in CRP before and after benzathine penicillin treatment.

Results: Twenty-nine syphilitic patients and three control groups (10 men who have sex with men (MSM) taking pre-exposure prophylaxis, 10 HIV-infected patients without syphilis, and $12 \mathrm{HIV-infected} \mathrm{patients} \mathrm{with} \mathrm{previous} \mathrm{syphilis)} \mathrm{were} \mathrm{enrolled.} \mathrm{All} 29$ syphilitic patients were MSM, and 21 patients (72\%) were infected with HIV. Overall, 41\% (12/29) of the patients developed the JHR. The active syphilis groups had significantly higher serum levels of CRP (median 11,761 ng/mL, IQR 2986-19,061 ng/mL). There were no significant differences in the serum levels of CRP before or after benzathine penicillin treatment. The 12 patients with the JHR had significantly higher CRP levels before benzathine penicillin treatment $(16,262 \mathrm{ng} / \mathrm{mL}$ [IQR 12,033-26,150 ng/mL] vs $3489 \mathrm{ng} / \mathrm{mL}$ [IQR 924-160,640] $\mathrm{ng} / \mathrm{mL}, \mathrm{p}=0.0059,95 \%$ CI $4002-17,098 \mathrm{ng} / \mathrm{mL}$, area under the curve $0.799,95 \%$ CI $0.632-$ 0.966, sensitivity 1, specificity 0.647 , with a CRP cut-off value of $4569.32 \mathrm{ng} / \mathrm{mL}$ ).

Conclusion: A high baseline CRP level can predict the occurrence of the JHR in syphilitic patients treated with benzathine penicillin.

Keywords: C-reactive protein, Jarisch-Herxheimer reaction, syphilis

\section{Introduction}

The Jarisch-Herxheimer reaction (JHR) was named after Austrian and German dermatologists who described it in 1895 and 1902 in patients with syphilis who developed exacerbations of skin lesions after treatment with mercurial compounds. $^{1-3}$ After penicillin became the drug of choice for syphilis in the 1940s, cases of the JHR were reported during the first day of treatment in early syphilitic patients manifesting as fever, chills, headache, myalgia, and exacerbation of skin rashes. The JHR has also been reported in other spirochetal infections, including Lyme disease, leptospirosis, and relapsing fever (RF), after treatment with 
penicillins and other antibiotics such as cephalosporins, quinolones, and macrolides. ${ }^{4-10}$

Yang et al reported an overall rate of JHR of 31.5\% (34.6\% in HIV-infected patients and $25.2 \%$ in HIVuninfected patients) among 355 patients with syphilis who received penicillin treatment. ${ }^{11}$ In multivariate analysis, the risk factors for the JHR included high rapid plasma reagin (RPR) titers, early syphilis and no prior penicillin treatment. Another study showed that treatment with azithromycin was associated with a lower risk of the JHR than that with benzathine penicillin $G$ in HIV-positive patients with early syphilis. ${ }^{10}$ In addition, Treponema pallidum strains have not been associated with the JHR among patients with syphilis receiving penicillin or doxycycline therapy. ${ }^{12}$

The causes of inflammation in the JHR are multifactorial. It is likely that penicillin rapidly alters the morphology of dividing spirochaetes, making them susceptible to phagocytosis and acting as a potent stimulus for cytokine release. ${ }^{13}$ Loveday and Bingham examined changes in intravascular complement, kininogen, and histamine during the JHR in nine patients with secondary syphilis, and found that there was appreciable activation of early components of the classic pathway of the complement system. ${ }^{14}$

Spirochetal inflammatory substances include lipoproteins and non-endotoxin pyrogens that can cause increases in cytokines. ${ }^{15-18}$ Massive releases of the cytokines TNF$\alpha$, IL-6 and IL-8 have been reported in patients with RF who develop the JHR after penicillin treatment. ${ }^{19}$ In addition, studies on patients with RF have reported increases in the concentrations of pro-inflammatory cytokines in the first 2 hours after antibiotic treatment, when spirochetes are cleared from the blood. ${ }^{19,20}$ However, increases in blood levels of TNF- $\alpha$, IL- 6 and IL- 8 are unlikely to initiate the JHR, because chills and an elevated temperature start as early as 30 minutes to 1 hour after antibiotic treatment. ${ }^{19,21,22}$ Increases in cytokines are evident only about 2 hours after antibiotic treatment when the JHR has already been fully expressed. Thus, the increases in cytokines appear to be the result of the JHR rather than its cause, while contributing to the intensity of the reaction as shown by the amelioration after anti-TNF antibody treatment. ${ }^{23}$

As an acute inflammatory protein, levels of C-reactive protein (CRP) increase at sites of infection or inflammation. ${ }^{24} \mathrm{CRP}$ can further active the complement system and promote phagocytosis. ${ }^{25}$ An elevated CRP level in early syphilitic patients has been reported, ${ }^{26}$ and a high baseline CRP level has been associated with severe $\mathrm{JHR}^{27}$

Most previous studies on cytokines in JHR were published decades ago and evaluated patients with RF. Therefore, the aims of this study were to evaluate the role of baseline CRP in patients with active syphilis and JHR. We also aimed to evaluate changes in CRP after the first dose of benzathine penicillin treatment in patients with active syphilis. Further, we aimed to identify the best serum CRP cutoff level to predict the JHR before benzathine penicillin treatment.

\section{Methods}

\section{Ethical Statement}

This study complied with ethical considerations involving human subjects, and all information obtained followed the principles of the Declaration of Helsinki. This study was approved by the Institutional Review Board of Kaohsiung Veterans General Hospital (VGHKS18-CT8-34). All patients were informed about the purpose of the study verbally and a written informed consent was obtained from each participant.

\section{Study Design and Procedures}

This prospective cohort study was conducted at Kaohsiung Veterans General Hospital, a 1485-bed medical center in southern Taiwan. The study period was from July 2018 to October 2020. Demographic, pharmacologic, serologic and concurrent infection data were collected. We included active syphilitic patients aged $\geq 20$ years who had received a first dose of benzathine penicillin treatment. Active syphilis was defined as a new reactive RPR (RPR Card test; Becton-Dickinson, Sparks, MD, USA) and Treponema pallidum particle agglutination test (SERODIA-TPPA; Fujirebio, Tokyo, Japan). ${ }^{28}$ In the patients who had previously received syphilis treatment, a documented decrease in nontreponemal titers followed by a four-fold increase in the RPR titer or recurrence of lesions of primary or secondary syphilis were used to indicate a new infection. ${ }^{29}$ The JHR was defined as the presence of fever and/or acute exacerbations of maculopapular skin rashes within 24 hours of benzathine penicillin therapy. ${ }^{10}$ Ten men who have sex with men (MSM) who were taking pre-exposure prophylaxis (PrEP), 10 HIV-infected patients without syphilis, and 12 HIVinfected patients with previous syphilis were also enrolled 
as control groups to evaluate the serum baseline CRP level in patients without active syphilis.

Immediately before receiving benzathine penicillin $(2.4$ $\mathrm{mu}$ intramuscular injection) for syphilis, $10 \mathrm{cc}$ of whole blood was obtained from the patients. Another $10 \mathrm{cc}$ of whole blood was then obtained 2-12 hours after benzathine penicillin treatment to analyze changes in CRP. The choice of one weekly or three weekly doses of benzathine penicillin treatment was decided by clinical physicians and the patients. After centrifugation, the serum was stored at $-20^{\circ} \mathrm{C}$ for further analysis. The patients were monitored for any adverse effects after penicillin treatment at the outpatient clinic, and a phone call was arranged on the next day. We also collected $10 \mathrm{cc}$ of whole blood from the three control groups to check the baseline serum CRP level.

\section{Enzyme-Linked Immunosorbent Assay (ELISA) for CRP Levels}

The concentration of serum CRP was measured using ELISA Kits (Human C-Reactive Protein/CRP DuoSet ELISA, DY 1707, R \& D Systems, Inc., USA) according to the manufacturer's instructions. In brief, a 96-well microplate was prepared. The capture antibody was diluted to the working concentration in phosphate buffered saline (PBS) and coated on the 96-well microplate. The microplate was then sealed and incubated overnight at room temperature. Wells of the ELISA plate were first coated with antibodies that captured CRP in serum specimens after adding the specimens to the wells. Biotinylated detection antibodies and streptavidinlabeled horseradish peroxidase were then added to the wells. Substrate (3,3,5,5-tetramethylbenzidine) solution was used for visualization. Reactions were stopped with $2 \mathrm{~N}$ sulfuric acid. Optical density values were read at $450 \mathrm{~nm}$.

\section{Statistical Analysis}

Statistical analysis was performed using Statistical Package for Social Sciences (SPSS) software (version 21, SPSS, Inc., an IBM Company, Chicago, IL, USA). Continuous variables were expressed as median and interquartile range (IQR), and categorical variables were expressed as percentages and numbers. The Kruskal-Wallis test was used to compare the levels of CRP in different groups, and the Wilcoxon signed-rank test was used to compare changes in CRP before and after benzathine penicillin treatment. A p-value $\leq 0.05$ was considered to be statistically significant. Receiver operating characteristic (ROC) curve analysis was used to define the best pre-treatment serum CRP cutoff value to predict the occurrence of the JHR.

\section{Results}

A total of 29 syphilitic patients and three control groups (10 MSM taking PrEP, 10 HIV-infected patients without syphilis, and 12 HIV-infected patients with previous syphilis) were enrolled. All 29 syphilitic patients were MSM with a median age of 30 years (IQR: 25-37 years), and 21 (72\%) were HIV-infected. The median RPR titer before treatment was 128 (IQR: 64-256). Overall, 48\% (14/29) of the patients had a newly diagnosed syphilis infection, and 52\% (15/29) had syphilis reinfection. Fifty-five percent of the patients (16/29) received only one dose of benzathine penicillin treatment, one patient $(3 \%, 1 / 29)$ received a 2 -weekly dose, and $41 \%(12 / 29)$ received a 3-weekly dose of benzathine penicillin therapy. The time interval from the first dose of benzathine penicillin treatment to the second blood sampling after treatment was 3.58 hours (IQR 2.35-4.16). The median time between the onset of the JHR and first benzathine penicillin treatment was 5 hours (IQR: 3.5-7.2 hours) (Table 1).

In total, $41 \%(12 / 29)$ of the patients developed the JHR, with presentations of fever $(n=10)$, exacerbated skin rash $(n=9)$, dizziness/headache $(n=4)$ and rigor $(n=2)$ (Table 2). There were significantly higher serum levels of CRP in the active syphilis groups compared to the control groups at baseline (Table 3 and Figure 1). Further analysis showed that the patients with the JHR had higher CRP concentrations before and after benzathine penicillin treatment (before treatment: 3488.6 $\mathrm{ng} / \mathrm{mL}$ [IQR 924-16,064] vs $16,262 \mathrm{ng} / \mathrm{mL}$ [IQR 12,032-26,150], $\mathrm{p}=0.0059$, 95\% CI 4002-17,098; after treatment: $4328 \mathrm{ng} / \mathrm{mL}$ [IQR 482-13,328] vs 16,159 ng/ $\mathrm{mL} \quad[\mathrm{IQR}$ 9352-24,561], $\mathrm{p}=0.0051,95 \%$ CI 395417,401) (Table 4 and Figure 2). The serum CRP levels were further analyzed in 21 patients with HIV infection, and the results also showed that those with the JHR had higher CRP concentrations before and after benzathine penicillin treatment (before treatment: $3280 \mathrm{ng} / \mathrm{mL}$ [IQR 1080-18,732] vs 14,954 ng/mL [IQR 11,761-27,160], $\mathrm{p}=0.0056,95 \% \mathrm{CI}-1808-17,637$; after treatment: 3713 $\mathrm{ng} / \mathrm{mL}$ [IQR 527-15,555] vs 18,131 ng/mL [IQR 900325,183], $\mathrm{p}=0.031,95 \%$ CI 667-20,300) (Table 4 and 
Table I Demographic Data of the 29 Patients with Syphilis

\begin{tabular}{|c|c|c|}
\hline \multicolumn{2}{|l|}{ Parameters } & \multirow{2}{*}{$\begin{array}{l}\begin{array}{l}\text { Patient } \\
\text { Number (\%) } \\
\mathbf{N}=29\end{array} \\
29(100)\end{array}$} \\
\hline Gender & Male & \\
\hline Age (years) & $\begin{array}{l}\text { Median } \\
\text { IQR }\end{array}$ & $\begin{array}{l}30 \\
25-37\end{array}$ \\
\hline Risk factor & MSM & $29(100)$ \\
\hline HIV co-infection & $\begin{array}{l}\text { No } \\
\text { Yes }\end{array}$ & $\begin{array}{l}8(27.6) \\
21(72.4)\end{array}$ \\
\hline $\begin{array}{l}\text { HIV viral load (copies } / \mathrm{mL}) \text { at } \\
\text { enrollment }(\mathrm{N}=2 \mathrm{I})\end{array}$ & $\begin{array}{l}\text { Median } \\
\text { IQR }\end{array}$ & $\begin{array}{l}<20 \\
<20-18,966\end{array}$ \\
\hline CD4 count at enrollment $(\mathrm{N}=2 \mathrm{I})$ & $\begin{array}{l}\text { Median } \\
\text { IQR }\end{array}$ & $\begin{array}{l}526 \\
310-707\end{array}$ \\
\hline RPR titer before treatment & $\begin{array}{l}\text { Median } \\
\text { IQR }\end{array}$ & $\begin{array}{l}\mathrm{I}: 128 \\
\mathrm{I}: 64-1: 256\end{array}$ \\
\hline Syphilis episode & $\begin{array}{l}\text { First episode } \\
\geq 2\end{array}$ & $\begin{array}{l}14(48.3) \\
15(51.7)\end{array}$ \\
\hline $\begin{array}{l}\text { Treatment of syphilis (benzathine } \\
\text { penicillin } 2.4 \mathrm{mu} \text { ) }\end{array}$ & $\begin{array}{l}\text { I shot } \\
2 \text { shots } \\
3 \text { shots }\end{array}$ & $\begin{array}{l}16(55.2) \\
1(3.4) \\
12(41.4)\end{array}$ \\
\hline $\begin{array}{l}\text { Time (hours) from treatment to } \\
\text { blood sampling for evaluation of } \\
\text { the JHR }\end{array}$ & $\begin{array}{l}\text { Median } \\
\text { IQR }\end{array}$ & $\begin{array}{l}3.58 \\
2.35-4.16\end{array}$ \\
\hline $\begin{array}{l}\text { JHR after benzathine penicillin } \\
\text { treatment }\end{array}$ & $\begin{array}{l}\text { Negative } \\
\text { Positive }\end{array}$ & $\begin{array}{l}17(58.6) \\
12(41.4)\end{array}$ \\
\hline $\begin{array}{l}\text { Time (hours) from treatment to } \\
\text { development of the JHR }\end{array}$ & $\begin{array}{l}\text { Median } \\
\text { IQR }\end{array}$ & $\begin{array}{l}5 \\
3.5-7.2\end{array}$ \\
\hline $\begin{array}{l}\text { JHR in patients with a first episode } \\
\text { of syphilis }(N=14)\end{array}$ & $\begin{array}{l}\text { Negative } \\
\text { Positive }\end{array}$ & $\begin{array}{l}7(50) \\
7(50)\end{array}$ \\
\hline $\begin{array}{l}\text { JHR in patients with recurrent } \\
\text { syphilis }(\mathrm{N}=15)\end{array}$ & $\begin{array}{l}\text { Negative } \\
\text { Positive }\end{array}$ & $\begin{array}{l}10(66.7) \\
5(33.3)\end{array}$ \\
\hline $\begin{array}{l}\text { RPR titer decreased at least } 4 \text {-fold } \\
\text { after I year }(\mathrm{N}=25)\end{array}$ & $\begin{array}{l}\text { YES } \\
\text { NO }\end{array}$ & $\begin{array}{l}21(84) \\
4(16)\end{array}$ \\
\hline
\end{tabular}

Abbreviations: HIV, human immunodeficiency virus; RPR, rapid plasma reagin; $\mathrm{IQR}$, interquartile range; MSM, men who have sex with men; JHR, JarischHerxheimer reaction.

Figure 3). We then compared changes in CRP before and after benzathine penicillin therapy in the patients with/without the JHR. The results showed that there were no significant changes in serum CRP level before and after benzathine penicillin treatment in the 12 patients with the JHR or in the 17 patients without the JHR (Table 5 and Figure 4). We further compared the baseline CRP level between patients with different
Table 2 Clinical Manifestations of 12 Syphilitic Patients with the Jarisch-Herxheimer Reaction After Benzathine Penicillin Treatment

\begin{tabular}{|l|l|}
\hline Parameters & Frequency (\%) \\
\hline Fever & $10(83)$ \\
Exacerbated skin rash & $9(75)$ \\
Chills & $2(17)$ \\
Dizziness/headache & $4(33)$ \\
Weakness & $1(8)$ \\
Myalgia & $1(8)$ \\
\hline
\end{tabular}

syphilis stages, RPR level, with or without HIV infection and with or without the JHR (Table 6). There were no significant changes in the baseline CRP level in the patients with primary or secondary syphilis, RPR titers, or HIV infection. However, the level was higher in the patients with the JHR. In ROC curve analysis, a CRP level of $4569.32 \mathrm{ng} / \mathrm{mL}$ had the highest area under the curve (AUC) of 0.799 ( $p=0.007,95 \%$ CI $0.632-0.966$, sensitivity 1 , specificity 0.647 ) (Figure 5 ).

\section{Discussion}

In this study, we found that there were statistically significantly higher baseline serum levels of CRP in the active syphilis group and also in 12 patients with the JHR before benzathine penicillin treatment. The best pretreatment serum CRP cutoff value to predict the occurrence of the JHR was $4569 \mathrm{ng} / \mathrm{mL}$ (AUC 0.799 , sensitivity 1 and specificity 0.647 ).

CRP is an acute phase reactant at sites of infection and inflammation, and it can promote phagocytosis of different pathogens. ${ }^{24,25}$ Increased CRP levels have been reported in patients with syphilitic uveitis compared to herpetic uveitis, and other infectious and noninfectious uveitis. ${ }^{30}$ Kindmark et al reported an increase in CRP in 10 patients with early syphilis who underwent penicillin treatment. ${ }^{27}$ They found that the baseline CRP level was not correlated to any clinical or serological activity of the infection. Moreover, the patients with high levels of baseline CRP prior to treatment had the most intense systemic reactions during the JHR. However, they did not report the best baseline CRP cutoff value to distinguish the presence the JHR, and the number of cases was small. In our study, we enrolled three additional control groups to compare the baseline CRP in patients with active syphilis and the JHR. The baseline CRP levels were significantly higher in the patients with active syphilis 
Table 3 Baseline CRP Levels of the 29 Patients with Active Syphilis and Three Control Groups

\begin{tabular}{|c|c|c|c|c|c|}
\hline & $\begin{array}{l}\text { HIV-Syphilis- } \\
\mathrm{N}=10\end{array}$ & $\begin{array}{l}\text { HIV+Syphilis- } \\
\mathrm{N}=10\end{array}$ & $\begin{array}{l}\text { HIV+Syphilis+ } \\
N=12\end{array}$ & $\begin{array}{l}\text { Active Syphilis } \\
\mathrm{N}=29\end{array}$ & $\begin{array}{l}\text { Kruskal-Wallis Test } \\
\text { (p-value) }\end{array}$ \\
\hline CRP & & & & & \\
\hline Median & 460.3 & |39|.2 & 739.6 & II,76|.0 & $<0.0001$ \\
\hline IQR & $123-1674$ & $254-2286$ & $394-1412$ & $2986-|9,06|$ & \\
\hline
\end{tabular}

Abbreviations: HIV, human immunodeficiency virus; IQR, interquartile range; CRP, C-reactive protein.

than in the three control groups without active syphilis (Figure 1). A possible explanation for the high baseline CRP level before treatment may be due to the effect of active syphilis itself. A previous study reported a higher CRP level in patients with active syphilis. ${ }^{26}$ In the patients with active syphilis in the present study, the baseline CRP levels were not correlated with RPR titer or stage of syphilis, but they were correlated with the presence of the JHR (Table 6). In addition, the patients with the JHR had a higher baseline CRP level and also higher CRP level after treatment (Figure 2). The reason why the patients who had the JHR after benzathine penicillin treatment had high serum CRP levels is unclear, but it may be due to differences in the serum CRP sampling time not corresponding to the dynamic changes in CRP. Another

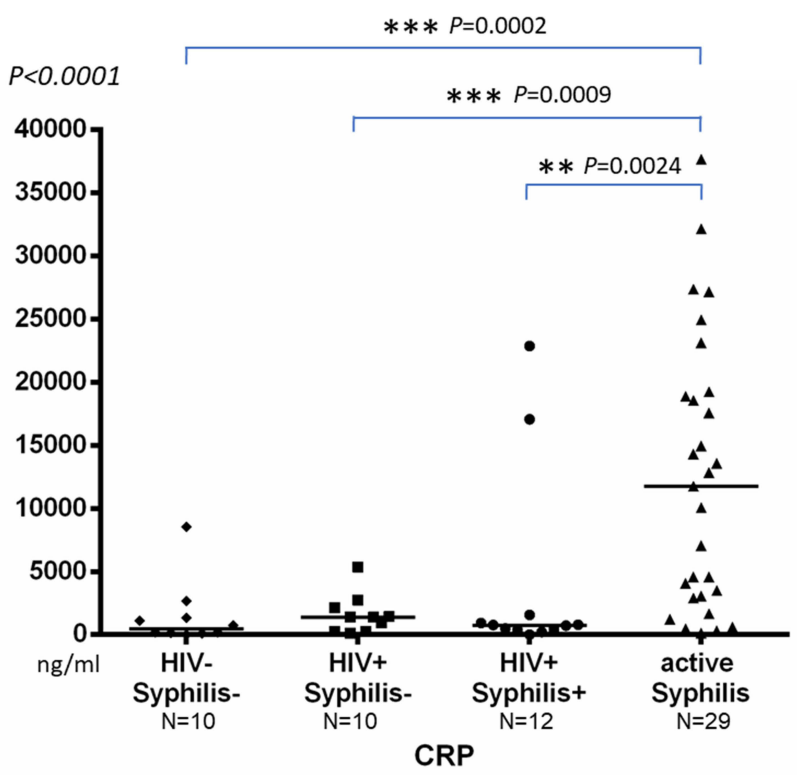

Figure I Baseline CRP levels among 29 patients with active syphilis and three control groups. $* * p<0.01$; $* * * P<0.001$.

Abbreviations: HIV- Syphilis-, men who have sex with men (MSM) who were taking pre-exposure prophylaxis (PrEP) and did not have HIV or syphilis infection; HIV+ Syphilis-, HIV-infected patients without syphilis; HIV+ Syphilis+, HIV-infected patients with previous syphilis. possible explanation is that the increased CRP level was induced by factors triggered by the JHR after benzathine penicillin treatment. The CRP level may have been elevated when syphilis infection occurred, and those with a high baseline CRP level before treatment would have had stronger inflammation after receiving penicillin treatment, in other words the JHR.

Our study subjects were recruited from the outpatient department and they did not require hospitalization. The time interval from the first dose of benzathine penicillin treatment to the second blood sampling after treatment was only 3.58 hours (IQR 2.35-4.16). This is in contrast to Kindmark et al's study, in which all 10 syphilitic patients were hospitalized for treatment and the CRP level and rectal temperature were measured regularly for up to 48 hours. Kindmark et al

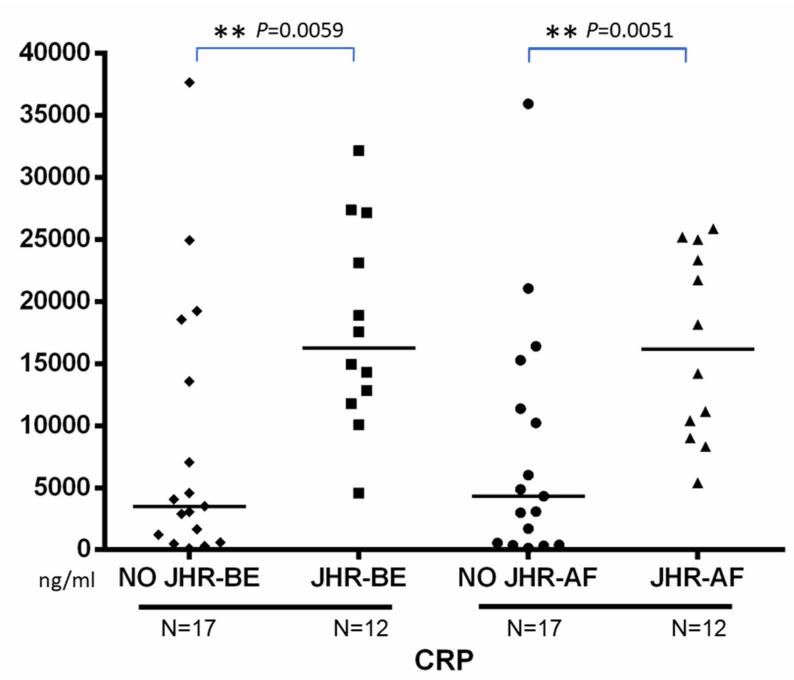

Figure 2 Changes in serum CRP levels before and after benzathine penicillin treatment among 12 syphilitic patients with the JHR and 17 without the JHR. $* * P<0.01$.

Abbreviations: JHR, Jarisch-Herxheimer reaction; BE, before benzathine penicillin treatment; $A F$, after benzathine penicillin treatment. 
Table 4 Changes in Serum CRP Levels Among Syphilitic Patients with and without the JHR After Benzathine Penicillin Treatment

\begin{tabular}{|c|c|c|c|c|c|c|}
\hline & $\begin{array}{l}\text { No JHR Before } \\
\text { Treatment }\end{array}$ & $\begin{array}{l}\text { JHR Before } \\
\text { Treatment }\end{array}$ & $\begin{array}{l}\text { Mann-Whitney U-Test } \\
\text { (p-value) } 95 \% \mathrm{Cl}\end{array}$ & $\begin{array}{l}\text { No JHR After } \\
\text { Treatment }\end{array}$ & $\begin{array}{l}\text { JHR After } \\
\text { Treatment }\end{array}$ & $\begin{array}{l}\text { Mann-Whitney U-Test } \\
\text { (p-value) } 95 \% \mathrm{CI}\end{array}$ \\
\hline \multicolumn{7}{|c|}{ All syphilitic patients ( $\mathrm{N}=29)$} \\
\hline & $N=17$ & $N=12$ & & $\mathrm{~N}=17$ & $N=12$ & \\
\hline \multicolumn{7}{|l|}{ CRP } \\
\hline Median & 3488.6 & 16,262 & 0.0059 & 4328 & 16,159 & 0.0051 \\
\hline IQR & $924-16,064$ & $12,032-26,150$ & $4002 \sim 17,098$ & $482-13,328$ & $9352-24,56 \mid$ & $3954 \sim 17,401$ \\
\hline \multicolumn{7}{|c|}{ HIV-infected syphilitic patients $(\mathrm{N}=2 \mathrm{I})$} \\
\hline & $N=14$ & $N=7$ & & $N=14$ & $N=7$ & \\
\hline \multicolumn{7}{|l|}{ CRP } \\
\hline Median & 3280.2 & $14,953.6$ & 0.0556 & 3712.6 & $18,13 \mid .4$ & 0.0309 \\
\hline IQR & $1080-18,732$ & $|I, 76|-27,160$ & $-1808 \sim 17,637$ & $527-15,555$ & $9003-25,183$ & $667 \sim 20,300$ \\
\hline
\end{tabular}

Abbreviations: CRP, C-reactive protein; JHR, Jarisch-Herxheimer reaction; IQR, interquartile range; HIV, human immunodeficiency virus.

reported an increase in CRP level in their syphilitic patients 12 hours after penicillin treatment, and that the level peaked 24 hours after treatment. These discrepancies in blood sampling may explain why there was no increase in CRP level in the JHR group after penicillin treatment in our study.

There are several limitations to this study. First, the sample size of the patients with the JHR was relatively small. However, we enrolled three additional groups to reduce bias by HIV and previous syphilis infection. Second, the time between the first and second CRP measurements was too short to be able to detect the serum CRP response after 24 hours or longer. Third, all syphilitic patients and control groups were taking antiretroviral agents during the study period. Therefore, the results may not be generalizable to other populations. Finally,

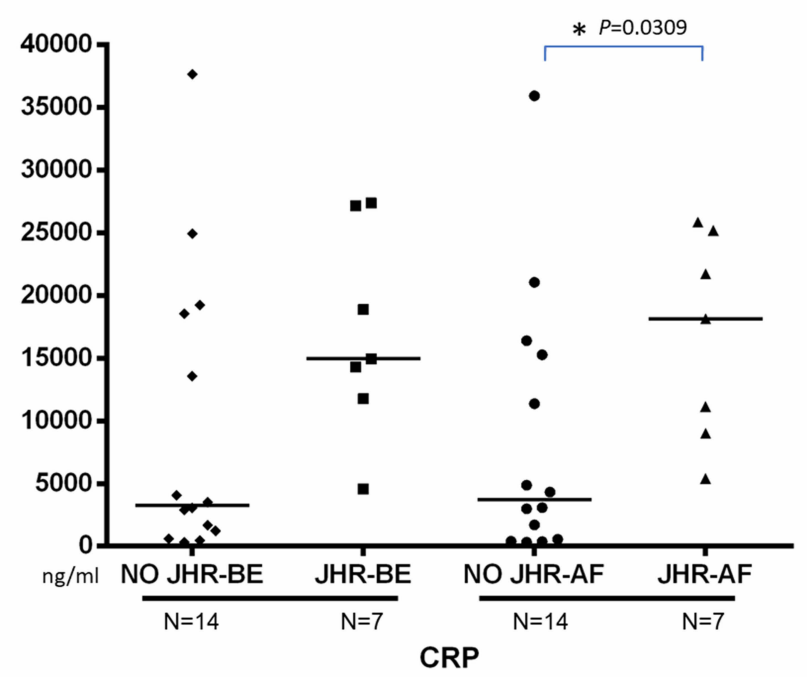

Figure 3 Changes in serum CRP levels among 7 HIV-infected syphilitic patients with the JHR and $14 \mathrm{HIV}$-infected syphilitic patients without the JHR after benzathine penicillin treatment. $* P<0.05$.

Abbreviations: JHR, Jarisch-Herxheimer reaction; BE, before benzathine penicillin treatment; AF, after benzathine penicillin treatment.

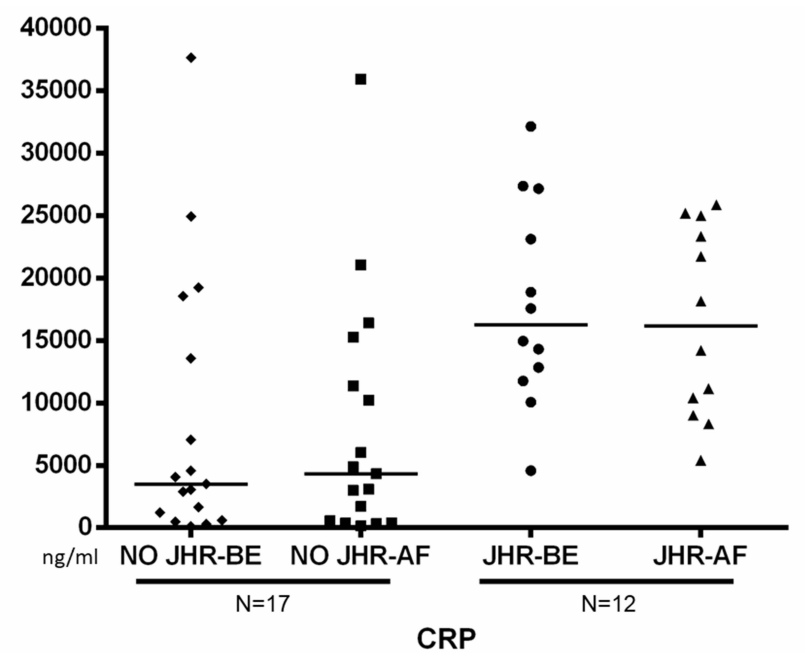

Figure 4 Changes in serum CRP levels before and after benzathine penicillin treatment among 12 syphilitic patients with the JHR and 17 without the JHR. Abbreviations: JHR, Jarisch-Herxheimer reaction; BE, before benzathine penicillin treatment; $A F$, after benzathine penicillin treatment. 
Table 5 Changes in Serum CRP Levels Before and After Benzathine Penicillin Treatment Among Syphilitic Patients with and without the JHR

\begin{tabular}{|l|l|l|l|l|l|l|}
\hline & $\begin{array}{l}\text { No JHR Before } \\
\text { Treatment } \\
\mathbf{N = 1 7}\end{array}$ & $\begin{array}{l}\text { No JHR After } \\
\text { Treatment } \\
\mathbf{N = 1 7}\end{array}$ & $\begin{array}{l}\text { Wilcoxon Signed } \\
\text { Rank Test ( } \boldsymbol{p} \text {-value) } \\
\mathbf{9 5 \%} \mathbf{C l}\end{array}$ & $\begin{array}{l}\text { JHR Before } \\
\text { Treatment } \\
\mathbf{N = 1 2}\end{array}$ & $\begin{array}{l}\text { JHR After } \\
\text { Treatment } \\
\mathbf{N = 1 2}\end{array}$ & $\begin{array}{l}\text { Wilcoxon Signed } \\
\text { Rank Test ( } \boldsymbol{p} \text {-value) } \\
\mathbf{9 5 \%} \mathbf{C I}\end{array}$ \\
\hline $\begin{array}{l}\text { CRP } \\
\text { Median }\end{array}$ & 3488.6 & 4328 & 0.7467 & 16,262 & 16,159 & 0.3013 \\
IQR & $924-16,064$ & $482-13,328$ & $-851 \sim 817$ & $12,032-26,150$ & $9352-24,561$ & $-3162 \sim 134 \mid$ \\
\hline
\end{tabular}

Abbreviations: CRP, C-reactive protein; JHR, Jarisch-Herxheimer reaction; IQR, interquartile range.

the findings were limited to patients with active syphilis who underwent benzathine penicillin treatment, and the serum CRP response may not be generalizable to patients with doxycycline or other antibiotic treatment.
In conclusion, high baseline CRP levels can predict the occurrence of the JHR in syphilitic patients treated with benzathine penicillin. Further large-scale studies are needed to verify our findings.

Table 6 Serum Baseline CRP Levels Prior to Treatment Between HIV Infection, Different RPR Titer, Syphilis Stage and JHR

\begin{tabular}{|c|c|c|c|}
\hline Parameter & Negative & Positive & M-W U-Test ( $p$-value) $95 \% \mathrm{Cl}$ \\
\hline HIV & $N=8$ & $N=21$ & \\
\hline Median & $\mathrm{II}, 457$ & $|I, 76|$ & 0.754 \\
\hline IQR & $5189-21,732$ & $2281-|9,06|$ & $-11,186 \sim 8493$ \\
\hline $\mathbf{R P R} \leqq 32$ & $N=4$ & $\mathrm{~N}=25$ & \\
\hline Median & 18,222 & 7050 & 0.1416 \\
\hline IQR & $14,028-25,089$ & $2281-18,905$ & $-|7,45| \sim 4245$ \\
\hline $\mathbf{R P R} \leqq 64$ & $N=10$ & $N=19$ & \\
\hline Median & 18,065 & 7050 & $0.246 I$ \\
\hline IQR & $3775-20,67 \mid$ & $1237-14,954$ & $-|4,498 \sim 4| 48$ \\
\hline $\mathbf{R P R} \leqq I 28$ & $N=18$ & $N=11$ & \\
\hline Median & 13,936 & 3489 & 0.1312 \\
\hline IQR & $4443-20,217$ & $472-14,954$ & $-14,304$ to 1828 \\
\hline$R P R \leqq 256$ & $N=24$ & $\mathrm{~N}=5$ & \\
\hline Median & 11,457 & $|1,76|$ & 0.9326 \\
\hline IQR & $2944-19,155$ & $2442-26,299$ & $-12,533$ to 12,709 \\
\hline JHR with fever or skin rash & $N=17$ & $N=12$ & \\
\hline Median & 3489 & 16,262 & 0.0059 \\
\hline IQR & $924-16,064$ & $12,033-26,150$ & 4002 to 17,098 \\
\hline JHR to fever & $N=19$ & $N=10$ & \\
\hline Median & 4066 & 16,914 & 0.0057 \\
\hline IQR & $1237-17,570$ & $12,576-27,2 \mid 3$ & 6002 to 18,560 \\
\hline JHR with skin rash & $N=20$ & $N=9$ & \\
\hline Median & 4317 & 17,570 & 0.0264 \\
\hline IQR & $1343-17,496$ & I I,457-25,245 & 650 to 16,958 \\
\hline Syphilis stage & N=7 (primary syphilis) & $\mathrm{N}=22$ (secondary syphilis) & \\
\hline Median & 2901 & 13,208 & 0.1428 \\
\hline IQR & $1237-19,249$ & $4443-19,935$ & -1818 to 15,385 \\
\hline
\end{tabular}

Abbreviations: HIV, human immunodeficiency virus; RPR, rapid plasma reagin; IQR, interquartile range; JHR, Jarisch-Herxheimer reaction; CRP, C-reactive protein. 


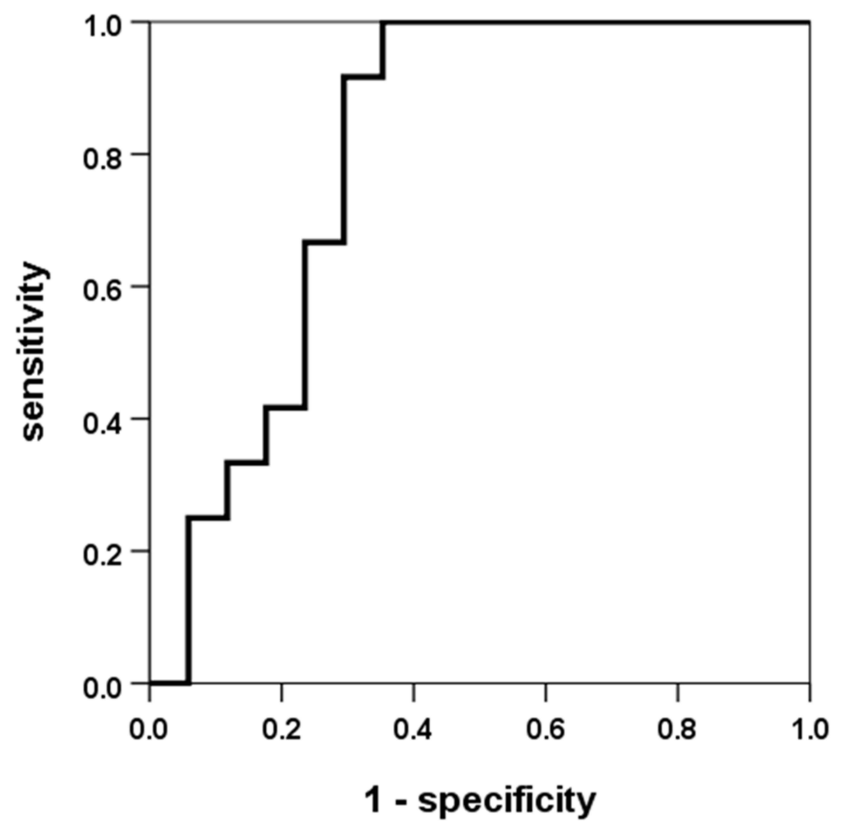

Figure 5 ROC curve for serum CRP to differentiate the occurrence of the JHR among 29 syphilitic patients treated with benzathine penicillin.

\section{Disclosure}

The authors report no conflicts of interest in this work.

\section{References}

1. Aronson IK, Soltani K. The enigma of the pathogenesis of the Jarisch-Herxheimer reaction. Br J Vener Dis. 1976;52:313-315. doi:10.1136/sti.52.5.313

2. Belum GR, Belum VR, Arudra SKC, Reddy BSN. The Jarisch-Herxheimer reaction revisited. Travel Med Infect Dis. 2013;11:231-237. doi:10.1016/j.tmaid.2013.04.001

3. Pound MW, May DB. Proposed mechanisms and preventative options of Jarisch-Herxheimer reactions. J Clin Pharm Ther. 2005;30:291-295.

4. Takamizawa S, Gomi H, Shimizu Y, Isono H, Shirokawa T, Kato M. Leptospirosis and Jarisch-Herxheimer reaction. QJM. 2015;108:967-968. doi:10.1093/qjmed/hcv077

5. Pimenta D, Democratis J. Risky behaviour: a rare complication of an uncommon disease in a returning traveller. BMJ Case Rep. 2013;2013:pii:bcr-2013-201075.

6. Gallardo C, Williams-Smith J, Jaton K, et al. Leptospirosis in a family after whitewater rafting in Thailand. Rev Med Suisse. 2015;11:872-876.

7. Webster G, Schiffman JD, Dosanjh AS, Amieva MR, Gans HA, Sectish TC. Jarisch-Herxheimer reaction associated with ciprofloxacin administration for tick-borne relapsing fever. Pediatr Infect Dis J. 2002;21:571-573. doi:10.1097/00006454-200206000-00020

8. Hoekstra KA, Kelly MT. Elevated troponin and Jarisch- Herxheimer reaction in tick-borne relapsing fever: a case report. Case Rep Infect Dis. 2011;2011:950314. doi:10.1155/2011/950314

9. Nizič T, Velikanje E, Ružić-Sabljić E, Arnež M. Solitary Erythema migrans in children: comparison of treatment with Clarithromycin and Amoxicillin. Wien Klin Wochenschr. 2012;124(13-14):427-433. doi:10.1007/s00508-012-0194-1

10. Tsai MS, Yang CJ, Lee NY, et al. Jarisch-Herxheimer reaction among HIV positive patients with early syphilis: azithromycin versus benzathine penicillin G therapy. J Int AIDS Soc. 2014;17:18993. doi:10.7448/IAS.17.1.18993
11. Yang CJ, Lee NY, Lin YH, et al. Jarisch-Herxheimer reaction after penicillin therapy among patients with syphilis in the era of the HIV infection epidemic: incidence and risk factors. Clin Infect Dis. 2010;51:976-979. doi:10.1086/656419

12. Arando M, Fernandez-Naval C, Mota-Foix M, et al. The Jarisch-Herxheimer reaction in syphilis: could molecular typing help to understand it better? J Eur Acad Dermatol Venereol. 2018;32:1791-1795. doi:10.1111/jdv.15078

13. Griffin GE. Cytokines involved in human septic shock-the model of the Jarisch-Herxheimer reaction. J Antimicrob Chemother. 1998;41 (Suppl A):25-29. doi:10.1093/jac/41.suppl_1.25

14. Loveday C, Bingham JS. Changes in intravascular complement, kininogen, and histamine during Jarisch-Herxheimer reaction in secondary syphilis. Genitourin Med. 1985;61:27-32. doi:10.1136/sti.61. 1.27

15. Akins DR, Purcell BK, Mitra MM, Norgard MV, Radolf JD. Lipid modification of the 17-kilodalton membrane immunogen of Treponema pallidum determines macrophage activation as well as amphiphilicity. Infect Immun. 1993;61:1202-1210. doi:10.1128/iai. 61.4.1202-1210.1993

16. Bulut Y, Faure E, Thomas L, Equils O, Arditi M. Cooperation of Toll-like receptor 2 and 6 for cellular activation by soluble tuberculosis factor and Borrelia burgdorferi outer surface protein A lipoprotein: role of toll-interacting protein and IL-1 receptor signaling molecules in Toll-like receptor 2 signaling. J Immunol. 2001;167:987-994. doi:10.4049/jimmunol.167.2.987

17. Butler T, Hazen P, Wallace CK, Awoke S, Habte-Michael A. Borrelia recurrentis infection: pathogenesis of fever and petechiae. J Infect Dis. 1979;140:665-675. doi:10.1093/infdis/140.5.665

18. Yang CW, Hung CC, Wu MS, et al. Toll-like receptor 2 mediates early inflammation by leptospiral outer membrane proteins in proximal tubule cells. Kidney Int. 2006;69:815-822. doi:10.1038/sj. ki.5000119

19. Negussie Y, Remick DG, DeForge LE, Kunkel SL, Eynon A, Griffin GE. Detection of plasma tumor necrosis factor, interleukins 6 , and 8 during the Jarisch-Herxheimer reaction of relapsing fever. $J$ Exp Med. 1992;175:1207-1212. doi:10.1084/jem.175.5.1207

20. Cuevas LE, Borgnolo G, Hailu B, Smith G, Almaviva M, Hart CA. Tumour necrosis factor, interleukin-6, and C-reactive protein in patients with louse-borne relapsing fever in Ethiopia. Ann Trop Med Parasitol. 1995;89:49-54. doi:10.1080/00034983.1995.11812928

21. Dworkin MS, Shoemaker PC, Fritz CL, Dowell ME, Anderson DE. The epidemiology of tick-borne relapsing fever in the United States. Am J Trop Med Hyg. 2002;66:753-758.

22. Coxon RE, Fekade D, Knox K, et al. The effect of antibody against TNF alpha on cytokine response in Jarisch-Herxheimer reactions of louse-borne relapsing fever. QJM. 1997;90:213-221. doi:10.1093/ qjimed/90.3.213

23. Fekade D, Knox K, Hussein K, et al. Prevention of JarischHerxheimer reactions by treatment with antibodies against tumor necrosis factor $\alpha$. $N$ Engl J Med. 1996;335:311-315. doi:10.1056/ NEJM199608013350503

24. Pepys MB. C-reactive protein and the acute phase response. Nature. 1982;296:12. doi:10.1038/296012a0

25. Kindmark CO. Stimulating effect of C-reactive protein on phagocytosis of various species of pathogenic bacteria. Clin Exp Immunol. 1971;8:941-948.

26. Gibowski M. C-reactive protein (CRP) in the serum of patients with early acquired syphilis. Przegl Dermatol. 1972;59:23-27.

27. Kindmark CO, Möller H, Persson K. C-reactive protein, C3, C4 and properdin during the Jarisch-Herxheimer reaction in early syphilis. Acta Med Scand. 1978;204:287-290. doi:10.1111/j.0954-6820.1978. tb08440.x

28. Wharton M, Chorba TL, Vogt RL, Morse DL, Buehler JW. Case definitions for public health surveillance. MMWR Recomm Rep. 1990;39(RR13):1-43. 
29. Zetola NM, Engelman J, Jensen TP, Klausner JD. Syphilis in the United States: an update for clinicians with an emphasis on HIV coinfection. Mayo Clin Proc. 2007;82:1091-1102. doi:10.4065/ 82.9.1091
30. Andreae CD, Smit DP, Makhoba NS, Kidd M, Walzl G, Chegou NN. Identification of potential biomarkers in peripheral blood supernatants of South African patients with syphilitic and herpetic uveitis. Ocul Immunol Inflamm. 2021;29:299-307.

\section{Publish your work in this journal}

Infection and Drug Resistance is an international, peer-reviewed openaccess journal that focuses on the optimal treatment of infection (bacterial, fungal and viral) and the development and institution of preventive strategies to minimize the development and spread of resistance. The journal is specifically concerned with the epidemiology of

Submit your manuscript here: https://www.dovepress.com/infection-and-drug-resistance-journa antibiotic resistance and the mechanisms of resistance development and diffusion in both hospitals and the community. The manuscript management system is completely online and includes a very quick and fair peerreview system, which is all easy to use. Visit http://www.dovepress.com/ testimonials.php to read real quotes from published authors. 